\title{
Reproductive traits of Gymnogeophagus labiatus (Teleostei, Cichlidae), in an upper stretch of Sinos river, Caraá, Brazil
}

\author{
Júlia T. Verba ${ }^{1}$, Vinicius R. Lampert ${ }^{2} \&$ Marco A. Azevedo ${ }^{3}$
}

1. Programa de Pós-Graduação em Ecologia, Instituto Nacional de Pesquisas da Amazônia, Av. André Araújo, 2936, 69011-970, Manaus, AM, Brazil. (juliatovarv@gmail.com)
2. Programa de Pós-Graduação em Biologia Animal, Universidade Federal do Rio Grande do Sul, Av. Bento Gonçalves, 9500, Prédio 43435, 91501-970, Porto Alegre, RS, Brazil. (biovrl@hotmail.com)
3. Setor de Ictiologia, Museu de Ciências Naturais, Fundação Zoobotânica do Rio Grande do Sul, Rua Dr. Salvador França, 1427, 90690-000, Porto Alegre, RS, Brazil. (marco-azevedo@fzb.rs.gov.br)

ABSTRACT. This work describes the reproduction of Gymnogeophagus labiatus (Hensel, 1870) from an upper stretch of Sinos river, southern Brazil, based on the analysis of 174 males and 132 females captured in monthly samples taken from January to December 2007. Results showed that reproductive activity occur in spring and summer although ripe males were found along the year. The standard length of the smallest ripe male was $104.74 \mathrm{~mm}(\mathrm{Lt})$ and the smallest ripe female was $55.00 \mathrm{~mm}(\mathrm{Lt})$. There was a significant difference in total sex ratio, with $1.32 \mathrm{males}$ to each female $\left(\chi^{2}=5.76\right)$. Males were much more abundant in March $(1.75$ males: 1 female $)$ and December $(5$ males: 1 female). Females were more abundant in the $62-77 \mathrm{~mm}$ interval ( 1 male: 2.36 female) while males were more abundant in the $77-92 \mathrm{~mm}$ size interval (2.57 males: 1 female). The largest length intervals were composed of only males. Mean absolute fecundity was $113.4( \pm 31.24 \mathrm{sd})$ and mean relative fecundity was $0.0125( \pm 0.0026 \mathrm{sd})$ oocytes $/ \mathrm{mg}$. In ripe ovaries, small-diameter oocytes were observed at high frequencies while larger ones occurred at lower frequencies. This pattern is common in fishes with asynchronous oocyte development. Characteristics of G. labiatus, such as low fecundity, asynchrony in oocyte development, multiple spawning, and its well-known parental care behavior, are consistent with an equilibrium strategy, as proposed for other cichlids.

KEYWORDS. Cichlid, Neotropical, reproduction, fecundity, oocyte development.

RESUMO. Características reprodutivas do cará Gymnogeophagus labiatus (Teleostei, Cichlidae) no curso superior do rio dos Sinos, Caraá, Brasil. Este trabalho descreve aspectos da reprodução de Gymnogeophagus labiatus (Hensel, 1870) do curso superior do rio dos Sinos, sul do Brasil, baseados na análise de 174 machos e 132 fêmeas. Foram realizadas coletas mensais de janeiro a dezembro de 2007, no município de Caraá, estado do Rio Grande do Sul. Os resultados mostraram que a atividade reprodutiva da espécie ocorre na primavera e verão, mas machos maduros podem ocorrer ao longo do ano. O comprimento padrão do menor macho maduro foi 104,74 mm e o da menor fêmea madura foi $55,00 \mathrm{~mm}$. Houve diferença significativa na proporção sexual total, indicando 1,32 machos para cada fêmea $\left(\chi^{2}=5,76\right)$. Os machos foram significativamente mais abundantes nos meses de março (1,75 machos: 1 fêmea) e dezembro ( 5 machos: 1 fêmea). Entre exemplares de 62 -77 $\mathrm{mm}$ as fêmeas foram mais abundantes (1 macho: 2,36 fêmeas) e entre aqueles de 77 -92 mm houve um número maior de machos (2,57 machos: 1 fêmea). Apenas machos compõem os maiores intervalos de comprimento. A fecundidade absoluta média foi de 113,4 ( $\pm 31,24 \mathrm{dp})$ e a fecundidade relativa média foi de $0,0125( \pm 0,0026 \mathrm{dp})$ oócitos $/ \mathrm{mg}$. Nas gônadas maduras observou-se a presença de oócitos de pequeno diâmetro em frequências altas e oócitos maiores, de diâmetro variado, em frequências sempre baixas. Esse padrão é comum para espécies de desenvolvimento ovocitário assincrônico. Os resultados obtidos para G. labiatus, tais como a baixa fecundidade, o desenvolvimento assincrônico dos ovócitos, as desovas múltiplas, além do cuidado parental já conhecido para a espécie, estão de acordo com a estratégia reprodutiva de equilíbrio, proposta para outras espécies de Cichlidae.

PALAVRAS-CHAVE. Ciclídeos, Neotropical, reprodução, fecundidade, desenvolvimento ovocitário.

Among freshwater Perciformes, the family Cichlidae is the most diverse, comprising about 1,300 described species with estimates reaching 1,900 species (Kullander, 1998). Cichlids are widespread in the freshwaters of Africa, Madagascar, India, Sri Lanka, Middle East, and in North, Central, and South Americas (Kullander, 2003). Cichlids usually have sedentary populations, are small to medium-sized fishes living in habitats with stable food resources (WINEMILLER, 1989). Most species typically live in lentic environments although some species are adapted to lotic systems. The high species diversity and the adaptive success of the group have been associated, at least in part, to the high diversity of reproductive behaviors (MCKAYE, 1984; MurRAY, 2001), which includes many types of parental care (Kullander, 2003). Species of Gymnogeophagus Miranda Ribeiro, 1918 are commonly known as "carás" and include nine species distributed through the Rio da Prata river basin and coastal systems of southern Brazil and northern Uruguay (KULlander, 2003). Gymnogeophagus labiatus (Hensel, 1870) is usually found in small streams and rivers with rocky substrates, strong currents, and clear, cool water (ReIs \& MALABARBA, 1988). As with other species of this genus, G. labiatus is a mouthbrooder (ReIs \& Malabarba, 1988), with females guarding offspring in the buccal cavity. There are no studies of reproduction and life history of this species to date. In many aspects, neotropical cichlids are far less studied than their African relatives (AXELROD, 1993). Thus, this work aims to describe and discuss aspects of the reproduction of G. labiatus, including reproductive period and possible relationships with biotic/abiotic factors, size at first gonadal maturation, sex ratio, fecundity, and oocyte development.

\section{MATERIAL AND METHODS}

Sampling was done monthly from January to December 2007 in the upper course of Sinos river $\left(29^{\circ} 45^{\prime} 51\right.$ 'S - 50 25'36”W), in southern Brazil. Sampling effort consisted of three seine hauls (mesh size of $5 \mathrm{~mm}$ between mesh knots), and gill nets (mesh 
Tab. I. Monthly variation in the mean values of gonadosomatic index (GSI), stomach repletion index (SRI), hepatosomatic index (HSI) and number of individuals $(\mathrm{N})$ of males and females of Gymnogeophagus labiatus (Hensel, 1870) from upper Sinos river, Caraá, RS, between January and December 2007 and photoperiod $(\mathrm{min})$, water temperature $\left(\mathrm{T} ;{ }^{\circ} \mathrm{C}\right)$ and rainfall $(\mathrm{mm})$. Standard deviation (sd).

\begin{tabular}{|c|c|c|c|c|c|c|c|c|c|c|c|}
\hline Month & $\begin{array}{l}\text { GSI } 0 \\
( \pm \text { sd })\end{array}$ & $\begin{array}{l}\text { SRI o } \\
( \pm \mathrm{sd})\end{array}$ & $\begin{array}{l}\text { HSI } 0^{\pi} \\
( \pm \text { sd })\end{array}$ & $\begin{array}{l}\mathrm{N} \\
\mathrm{O} \\
\end{array}$ & $\begin{array}{l}\text { GSI q } \\
( \pm \text { sd })\end{array}$ & $\begin{array}{l}\text { SRI + } \\
( \pm \mathrm{sd})\end{array}$ & $\begin{array}{r}\text { HSI q } \\
( \pm \text { sd })\end{array}$ & $\begin{array}{l}\mathrm{N} \\
+ \\
\end{array}$ & Photoperiod & $\mathrm{T}$ & Rainfall \\
\hline Jan & $0.007 \pm 0.005$ & $0.84 \pm 0.71$ & $0.57 \pm 0.49$ & 6 & $0.51 \pm 0.38$ & $0.62 \pm 0.23$ & $0.79 \pm 0.85$ & 19 & 837 & 26.8 & 80.6 \\
\hline Feb & $0.006 \pm 0.006$ & $0.72 \pm 0.45$ & $0.66 \pm 0.19$ & 13 & $0.66 \pm 0.56$ & $0.84 \pm 0.24$ & $0.88 \pm 0.17$ & 14 & 805 & 24.8 & 185.7 \\
\hline Mar & $0.012 \pm 0.014$ & $0.58 \pm 0.13$ & $0.61 \pm 0.13$ & 24 & $0.20 \pm 0.09$ & $0.66 \pm 0.12$ & $0.66 \pm 0.16$ & 19 & 739 & 24.8 & 172.0 \\
\hline Apr & $0.013 \pm 0.012$ & $0.40 \pm 0.15$ & $0.52 \pm 0.09$ & 6 & $0.16 \pm 0.04$ & $0.45 \pm 0.07$ & $0.41 \pm 0.01$ & 4 & 670 & 23.2 & 74.1 \\
\hline May & 0.011 & 0.64 & 0.81 & 1 & & & & 1 & 631 & 15.9 & 168.2 \\
\hline Jun & 0.018 & 0.88 & 0.75 & 5 & $0.27 \pm 0.08$ & $0.58 \pm 0.07$ & $0.94 \pm 0.13$ & 5 & 615 & 13.5 & 124.5 \\
\hline Jul & $0.015 \pm 0.007$ & $0.69 \pm 0.20$ & $0.82 \pm 0.07$ & 8 & $0.26 \pm 0.07$ & $0.90 \pm 0.31$ & $0.96 \pm 0.14$ & 5 & 640 & 12.8 & 233.5 \\
\hline Aug & $0.020 \pm 0.017$ & $0.71 \pm 0.13$ & $1.03 \pm 0.22$ & 18 & $0.35 \pm 0.08$ & $0.74 \pm 0.16$ & $0.89 \pm 0.16$ & 14 & 683 & 13.0 & 153.7 \\
\hline Sep & $0.025 \pm 0.021$ & $0.66 \pm 0.23$ & $0.91 \pm 0.24$ & 14 & $1.75 \pm 0.89$ & $0.70 \pm 0.08$ & $1.02 \pm 0.40$ & 12 & 742 & 20.1 & 222.9 \\
\hline Oct & $0.015 \pm 0.009$ & $0.54 \pm 0.19$ & $0.73 \pm 0.11$ & 5 & $1.45 \pm 1.63$ & $0.60 \pm 0.05$ & $0.95 \pm 0.16$ & 5 & 797 & 17.6 & 78.3 \\
\hline Nov & $0.007 \pm 0.003$ & $0.54 \pm 0.21$ & $0.68 \pm 0.11$ & 4 & $1.07 \pm 0.45$ & $0.66 \pm 0.24$ & $0.99 \pm 0.21$ & 5 & 832 & 23.0 & 137.9 \\
\hline Dec & $0.005 \pm 0.003$ & $0.42 \pm 0.07$ & $0.72 \pm 0.21$ & 20 & $1.08 \pm 0.16$ & $0.53 \pm 0.19$ & $0.86 \pm 0.12$ & 4 & 844 & 25.5 & 142.5 \\
\hline
\end{tabular}

sizes $15,30,40 \mathrm{~mm}$ ) set for $24 \mathrm{~h}$. Fish were fixed in $10 \%$ formalin and voucher specimens catalogued in the Coleção de Peixes do Museu de Ciências Naturais da Fundação Zoobotânica do RS (MCN 18800, 18801). Temperature was measured in the field; photoperiod and rainfall data were provided by the $8^{\text {th }}$ District of Meteorology, in Porto Alegre, RS. Standard length (SL, $\mathrm{mm})$, total weight $\left(\mathrm{W}_{\mathrm{t}}, \mathrm{g}\right)$, and gonad, stomach, and liver weights $\left(\mathrm{W}_{\mathrm{g}}, \mathrm{W}_{\mathrm{s}}, \mathrm{W}_{\mathrm{l}}, \mathrm{g}\right)$ were recorded for each specimen to the nearest $0.01 \mathrm{~mm}$ and $0.0001 \mathrm{~g}$. We used these data to calculate the gonadosomatic (GSI), stomach repletion (SRI), and hepatosomatic (HSI) indices according to these equations: $\mathrm{GSI}=\left(\mathrm{W}_{\mathrm{g}} .100\right) / \mathrm{W}_{\mathrm{t}}\left(\mathrm{V}_{\text {AZZOLER, 1996); }}\right.$ $\mathrm{SRI}=\left(\mathrm{W}_{\mathrm{s} .100)} / \mathrm{W}_{\mathrm{t}}(\mathrm{S}\right.$ ANTOS, 1978)$) ;$ and HSI $=\left(\mathrm{W}_{\mathrm{l}} .100\right) /$ $\mathrm{W}_{\mathrm{t}}$ (SAntos, 1978). Gonadal maturation stages were identified through macroscopic analysis following VAZZOLER (1996). Reproductive period was estimated by monthly variation in GSI and the frequency of ripe individuals. Spearman rank correlation was used to test for significance between biotic indices (GSI, SRI, and HSI) and abiotic data (temperature, photoperiod, and rainfall). Size at maturation was made using the length of the smallest ripe individual, male and female, as an estimate of the minimum size in which the species might be ready to reproduction (SATO \& Godinho, 1988). Sex ratio was estimated for the total sample as well as for monthly samples and standard-length classes $(15-\mathrm{mm}$ intervals). Fecundity and oocyte development were estimated by counting and measuring oocytes from 10 ripe females under a stereomicroscope with a ruled scaled ocular. Relative fecundity is given through the number of oocytes per milligram of female's total body weight, as suggested by ADEBISI (1987).

\section{RESULTS}

Along the study period, water temperature in Sinos river ranged from $12.8^{\circ} \mathrm{C}$, in July, to $26.8^{\circ} \mathrm{C}$, in January. These months corresponds to winter and summer in southern hemisphere. The photoperiod ranged from
615 min (June) to $844 \mathrm{~min}$ (December). As expected for temperate South America, the monthly rainfall data showed high variation along the year without well defined dry or wet seasons. The highest rainfall value was in July $(233.5 \mathrm{~mm})$ and the lowest $(74.1 \mathrm{~mm})$ in April (Tab. I).

Results from the analysis of 174 males (ranging from 24.58 to $156.38 \mathrm{~mm} \mathrm{SL}$ ) and 132 females (ranging from 17.9 to $83.59 \mathrm{~mm} \mathrm{SL}$ ) of G. labiatus showed a peak in mean GSI values in September along with a peak in the values of temperature as well as with the increase in photoperiod (Figs 1, 2; Tab. I). Ripe individuals were found from August to November, December, March and April (males) and from September to February (females) (Figs 3, 4), which defines a seasonal reproduction for this species, although high values of GSI can be found all along the year to males.

The Spearman rank correlation showed a significantly negative correlation between GSI mean values of males and photoperiod $(\mathrm{r}=-0.6105 ; \mathrm{P}=$ 0.0350 ) and a very significant negative correlation between GSI mean values of males and temperature $(r=-0.7206 ; P=0.0082)$. For females, a significantly positive correlation was found only between GSI mean values and photoperiod $(\mathrm{r}=0.6364 ; \mathrm{P}=0.0402)$. The monthly variation in the mean values of SRI, HSI and GSI for males (Fig. 5) showed similar behavior of the curves of SRI and HSI between some months. A significantly positive correlation between mean values of GSI and HSI was observed for males $(\mathrm{r}=0.6316 ; \mathrm{P}=$ 0.0276). The curves of SRI, HSI and GSI of females also showed a similar behavior but no significant correlations were detected ( $\mathrm{P}>0.05)$ (Fig. 6).

The standard length of the smallest ripe male was $104.74 \mathrm{~mm}$, and the smallest ripe female was $55.00 \mathrm{~mm}$.

The overall sex ratio of this G. labiatus population was highly skewed with 1.32 males: 1 female. Monthly sex ratios were near parity throughout the year, except for March and December where males were more abundant. There was a large difference in the size 

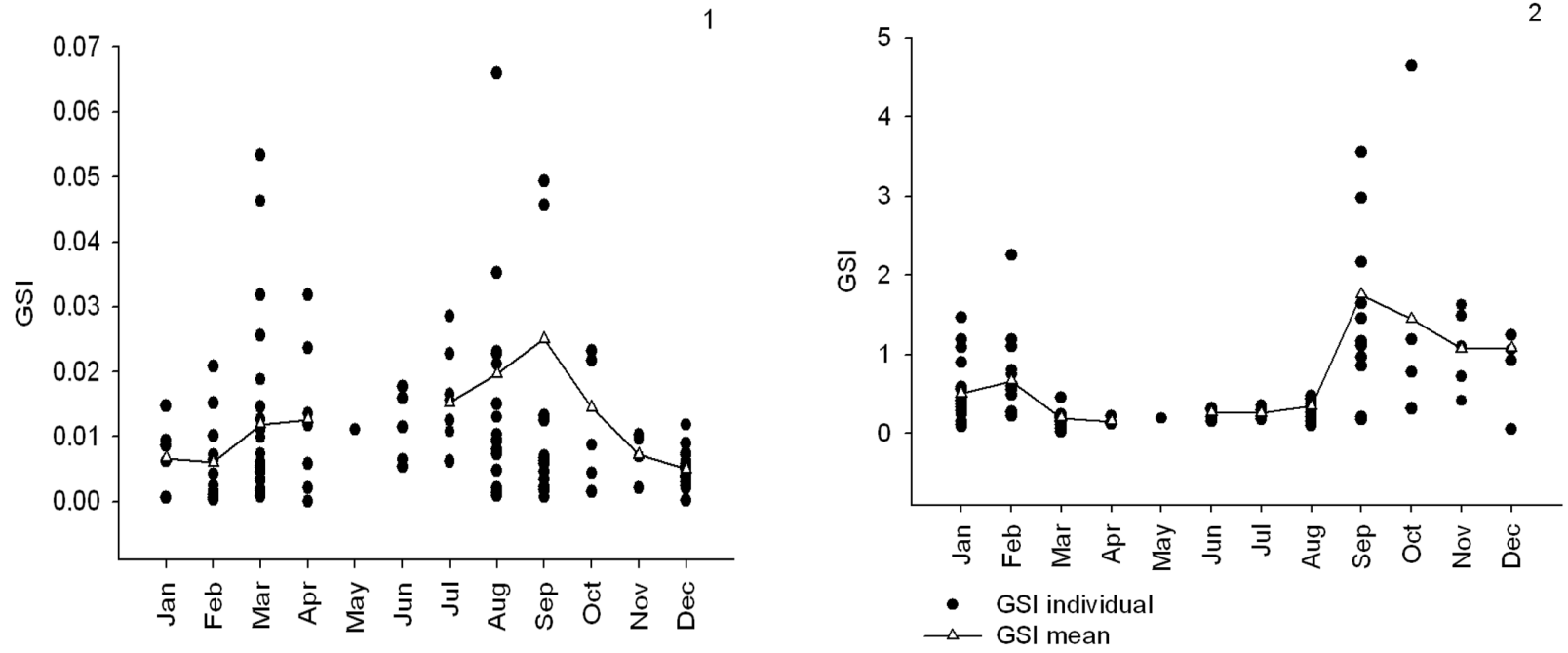

Figs. 1, 2. Monthly values of gonadosomatic index (GSI) of males (1) and females (2) of Gymnogeophagus labiatus (Hensel, 1870) from upper Sinos river, Caraá, RS, between January and December 2007.

distribution by gender. Females were more abundant at the $47+62 \mathrm{~mm}$ and $62+77 \mathrm{~mm}$ SL intervals, with more than twice the number of males in the later. Males were more abundant in the $17 \vdash-32 \mathrm{~mm}, 32$-47 mm e $77+92$ $\mathrm{mm} \mathrm{SL}$ intervals. Males reached the larger sizes so that the largest standard length intervals (above $92 \mathrm{~mm}$ ) were composed only by males (Tab. II).

Fecundity showed a linear relationship $\left(\mathrm{R}^{2}\right.$ $=0.4192$ ) with total weight. Absolute fecundity ranged from 64 to 174 oocytes, with a mean of $113.4( \pm 31.24 \mathrm{sd})$ and relative fecundity ranged from 0.0073 to 0.0176 oocytes per $\mathrm{mg}$, with a mean of $0.0125( \pm 0.0026 \mathrm{sd})$. The analysis of oocyte frequency by oocyte-diameter class showed the presence of small-diameter oocytes (previtellogenic) between 0.03 and $0.36 \mathrm{~mm}$ at high frequencies. Larger oocytes were also found but at lower frequencies (Fig. 7).

\section{DISCUSSION}

In temperate environments, the reproductive seasonality of fishes is usually related to temperature, photoperiod, and food availability (MCKAYE, 1984; PAYNE, 1986). Seasonal reproduction during spring and summer, when temperature and photoperiod are higher, has been noted for a large number of neotropical species (VAzzoler, 1996). However, many studies show that cichlid species can reproduce during different periods (BARBIERI et al., 1978; Lobón-Cerviá et al., 1993; Gurgel et al., 1994a,b; Hartz et al., 1999; Mazzoni \& Iglesias-Rios, 2002; Chellappa et al., 2003; GómezMarquez et al., 2003; Gomiero \& Braga, 2003).

As long as ripe females are found from September to February while males can be found with high values of GSI along the year, we suppose that females determine the reproductive period of G. labiatus. We conclude that this species have a long and seasonal reproductive period along six months, comprising the spring and summer in the southern hemisphere with a positive correlation with photoperiod. SANTOS \& FONTOURA (2000) report similar results to a population of Geophagus brasiliensis (Quoy \& Gaymard, 1824), which reproduces between September and April. Although the peaks of reproduction of males and females are coincident in this population, occurring in November and February, GSI curve of males showed small peaks indicating gonadal development in other months such as observed for G. labiatus in the present study. Females require a higher energetic investment to the development and maturation of their gametes rather than males (ForSGREN et al., 2002), which might explain the occurrence of mature males along the year while females concentrate their efforts to reproduction in a period of the year where environmental conditions are more favorable to the survival of offspring. This is corroborated by the correlations found between GSI and environmental factors. As long as males do not show a marked seasonal behavior in the maturation of their gonads, a negative correlation appeared. Females, on the other hand, showed a marked seasonality in gonadal maturation with high and low values of GSI in spring and summer and autumn and winter, respectively with a positive correlation to photoperiod which is low in winter and rises in spring and summer.

Sex-ratio analysis showed that males predominated over females in the population as a whole. They also grew larger so that in the largest standard-length intervals, there were only males in our samples, showing a marked sexual dimorphism by size. Males often reach larger sizes than females in other cichlid species which agrees with our results, but in those species the number of females is usually higher than the number of males what differs from our findings (HARTZ et al., 1999; Santos \& Fontoura, 2000; Chellappa et al., 2003; 
Tab. II. Sex ratio by months in Gymnogeophagus labiatus (Hensel, 1870) from upper Sinos river, Caraá, RS, between January and December 2007. Significant values of Chi-square $\left(\chi^{2}\right)$ are indicated by asterisks.

\begin{tabular}{cccc}
\hline Months & Females & Males & $\chi^{2}$ \\
\hline Jan & 19 & 14 & 0.76 \\
Feb & 23 & 20 & 0.21 \\
Mar & 24 & 42 & $4.91^{*}$ \\
Apr & 15 & 23 & 1.68 \\
May & 1 & 1 & 0.00 \\
Jun & 5 & 5 & 0.00 \\
Jul & 5 & 8 & 0.69 \\
Aug & 14 & 18 & 0.50 \\
Sep & 12 & 14 & 0.15 \\
Oct & 5 & 5 & 0.00 \\
Nov & 5 & 4 & 0.11 \\
Dec & 4 & 20 & $10.67^{*}$ \\
\hline
\end{tabular}
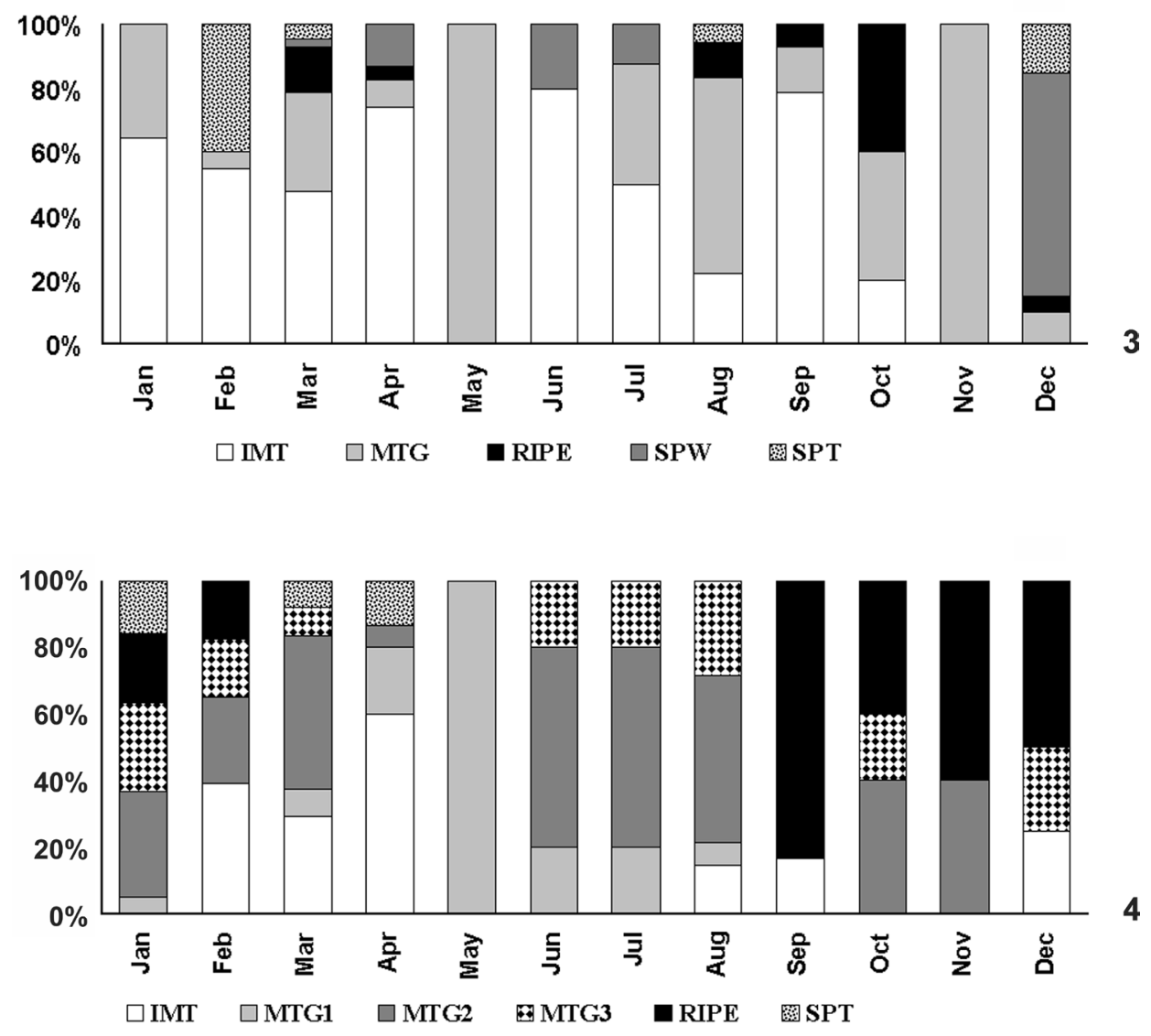

Figs. 3, 4. Monthly distribution of the gonadal maturation stages of males (3) and females (4) of Gymnogeophagus labiatus (Hensel, 1870) from upper Sinos river, Caraá, RS, between January and December 2007 (IMT, immature; MTG1, maturing 1; MTG2, maturing 2; MTG3, maturing 3; RIPE, Ripe; SPW, spawning; SPT, spent). 
Kullander, 2003). According to Fryer \& Iles (1972), in cichlid populations from African lakes, males are larger than females because their growth rate is higher. Although, according to HARTz et al. (1999), males of cichlids are larger and colorful due to their mating behavior, which may include territorial defense, competition for females, and also, the lower energetic cost for the development of sperm compared with oocytes.

Fishes that provide parental care usually produce a low number of oocytes, presumably because protection of eggs and larvae demand higher energetic cost. On the other hand, it guarantees a higher survival of progeny. Many Characiformes that show parental care have low fecundities, often between 20 to 400 oocytes (VAzzoler \& Menezes, 1992). Data on fecundity of neotropical cichlid species are scarce and usually do not take into account relative fecundity making standardized comparisons quite difficult. This feature, along with the fish length, although a raw approximation, might allow a comparison between species rather than the use of absolute fecundity. Studies show that some cichlid species may have low absolute fecundity, such as Apistogramma hoignei Meinken, 1965 (51 oocytes), Crenicichla geayi Pellegrin, 1903 (230) (WINEMILLER, 1989), and Gymnogeophagus lacustris Reis \& Malabarba, 1988 (131 to 253) (HARTz et al., 1999). Similarly, we found that G. labiatus has a low mean of 113.4 oocytes. On the other hand, other cichlids have higher values of fecundity, such as Aequidens pulcher (Gill, 1858) (861), Astronotus ocellatus (Agassiz, 1831) (2301), Caquetaia kraussii (Steindachner, 1879) (3702), Cichlasoma orinocense Kullander, 1983 (1287)

Tab. III. Sex ratio by standard length intervals and total in Gymnogeophagus labiatus (Hensel, 1870) from upper Sinos river, Caraá, RS, between January and December 2007. Significant values of Chi-square $\left(\chi^{2}\right)$ are indicated by asterisks.

\begin{tabular}{cccc}
\hline SL intervals & Females & Males & $\chi^{2}$ \\
\hline $17-32$ & 22 & 29 & 0.96 \\
$32-47$ & 14 & 22 & 1.78 \\
$47-62$ & 23 & 14 & 2.19 \\
$62-77$ & 66 & 28 & $15.36^{*}$ \\
$77-92$ & 7 & 18 & $4.84^{*}$ \\
$92-107$ & 0 & 20 & \\
$107-122$ & 0 & 17 & \\
$122-137$ & 0 & 17 & \\
$137-152$ & 0 & 7 & \\
$152-167$ & 0 & 2 & \\
Total & 132 & 174 & $5.76^{*}$ \\
\hline
\end{tabular}

(Winemiller, 1989), Geophagus brasiliensis (341 to 3191) (SAntos \& Fontoura, 2000; Mazzoni \& IglesiasRios, 2002), Cichla monoculus (Spix \& Agassiz, 1831) (3100 to 17987) (Chellappa et al., 2003; Gomiero \& Braga, 2004), C. kelberi (Kullander \& Ferreira, 2006) (6072) (Souza et al., 2008) and C. ocellaris (Bloch \& Schneider,1801) (13769) (Gomiero \& BragA, 2004). Gymnogeophagus labiatus is more closely related and have also similar size with species like G. brasiliensis and $G$. lacustris; the other species mentioned are smaller, or bigger, or not closely related to G. labiatus. Although all those species display brood protection, the type of parental care may affect the amount of oocytes produced. For example, mouthbrooding species, like G. labiatus, have their fecundity limited by buccal cavity volume (HARTz et al., 1999) while the substrate spawner G. brasiliensis do not show the same limitation (Goodwin et al., 1998). Goodwin et al. (1998) suggests that the evolution of traits such as the loss of adhesive threads on eggs (PETERs \& BERns, 1982), reduced fecundity, and increased egg size with higher juvenile survival (NoAkes \& BALON, 1982) have accompanied the evolution of mouthbrooding. According to LAGLER et al. (1977), for a given species, fecundity is inversely proportional to the level of parental care. The species size, the oocyte diameter of each species, and its reproductive strategy may all play a role in specific fecundity.

The pattern of oocyte development in G. labiatus was similar to that found in species whose oocyte development is asynchronous, as proposed by VAzZOLER (1996) suggesting a multiple spawning to this species. WinEMILLER (1989) has analyzed aspects of reproduction in six cichlid species and all of them showed a long reproductive period (six to twelve months) with two or more spawning events per year. Those species were characterized as acyclic spawners. In the same way, Satanoperca pappaterra (Heckel, 1840) (VAzzolER, 1996), Gymnogeophagus lacustris (HARTz et al., 1999), species of Cichla (Chellappa et al., 2003; Gomiero \& Braga, 2004; Souza et al., 2008) and Geophagus brasiliensis (BARBIERI et al., 1981), were characterized as multiple spawners, although the later was defined as total spawner by SANTOS \& FonTOURA (2000).

According to WINEMILLER (1989), fishes that exhibit a set of life-history traits such as an intermediate or long generation time, high investment in individual offspring, late maturation, non-seasonal reproduction, and long reproductive period may be characterized as equilibrium strategists, which is similar to the K-strategy as proposed by PIANKA (1970). As a group, cichlids tend to exhibit traits related to equilibrium strategy (Winemiller, 1989). Our data for G. labiatus, such as low fecundity, asynchronous oocyte development, multiple spawning, and mouthbrooding support that life-history model for cichlids. 


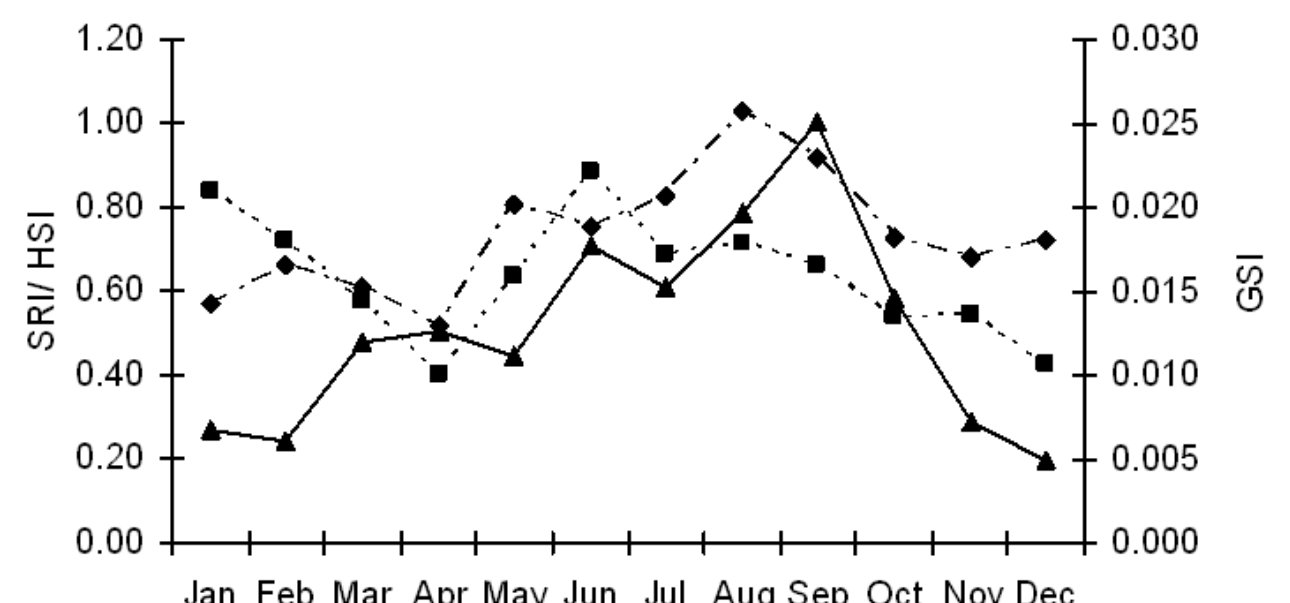

Jan Feb Mar Apr May Jun Jul Aug Sep Oct Nov Dec
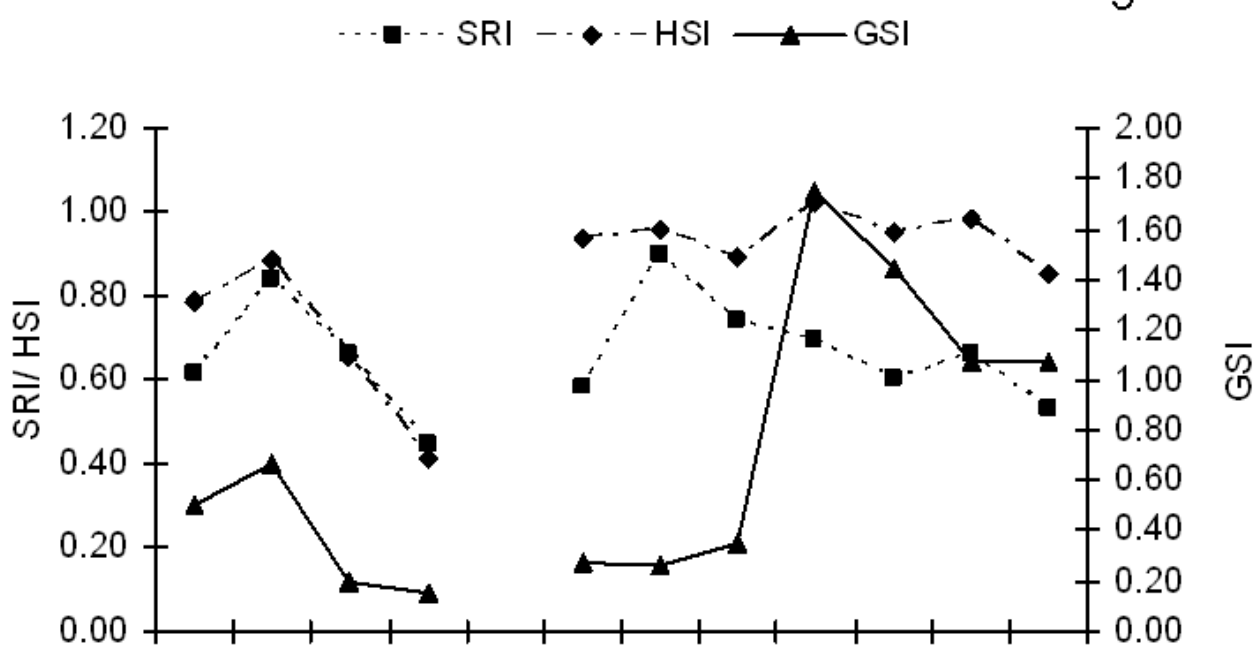

Jan Feb Mar Apr May Jun Jul Aug Sep Oct Nov Dec

$\cdots-\cdot \mathrm{SRI}-\cdots-\mathrm{HSI} \longrightarrow \mathrm{GSI}$

Figs. 5, 6. Monthly variation in the mean values of hepatosomatic index (HSI), stomach repletion index (SRI), and gonadosomatic index (GSI) of males (5) and females (6) of Gymnogeophagus labiatus (Hensel, 1870) from upper Sinos river, Caraá, RS, between January and December 2007.

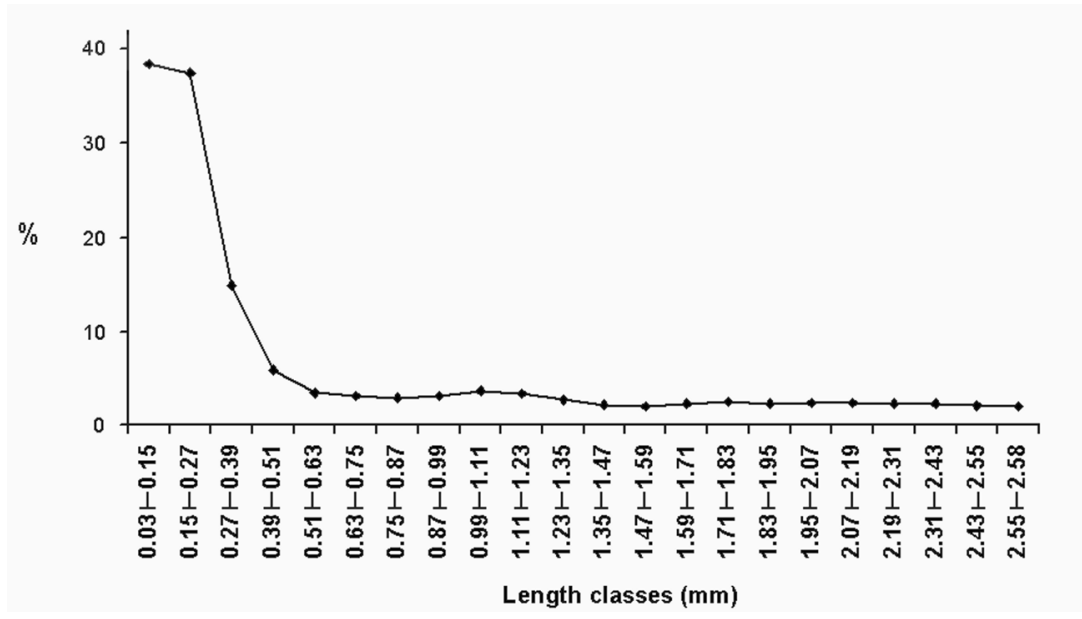

Fig. 7. Distribution of the frequencies of oocyte length intervals (mm) of 10 females of Gymnogeophagus labiatus (Hensel, 1870) from upper Sinos river, Caraá, RS, between January and December 2007. 


\section{REFERENCES}

Adebisi, A. A. 1987. The relationships between fecundities, gonadosomatic indices and egg sizes of some fishes of Ogun River, Nigeria. Archiv für Hydrobiologie 111:151-156.

AXELROD, H. R. 1993. The most complete colored lexicon of cichlids. New Jersey, Tropical Fish Hobbyist Publications. 863p.

Barbieri, G.; BARBIERI, M. \& Marins, M. 1978. Biologia de Geophagus brasiliensis (Quoy \& Gaimard, 1824), na Represa do Lobo, Estado de São Paulo. III: Aspectos quantitativos da reprodução. Anais da Academia Brasileira de Ciências 1:347-359.

1981. Sobre a anatomia e histologia de ovário de Geophagus brasiliensis (Quoy \& Gaimard, 1824) na represa do Lobo, Estado de São Paulo. Revista Brasileira Biologia 41:163-168.

Chellappa, S.; Câmara, M. R.; Chellappa, N. T.; Beveridge, M. C. M. \& Huntingford, F. A. 2003. Reproductive Ecology of a Neotropical Cichlid fish, Cichla monoculus (Osteichthyes: Cichlidae). Brazilian Journal of Biology 63(1):17-26.

Forsgren, E.; Reynolds, J. D. \& Berglund, A. 2002. Behavioral ecology of reproduction in fish. In: HART, P. J. B. \& REYNOLDS, J. D. eds. Handbook of Fish Biology and Fisheries. Oxford, Blackwell Publishing. v.1, p.225-247.

Fryer, G. \& Iles, T. D. 1972. The Cichlid Fishes of the Great Lakes of Africa: their Biology and Evolution. Edinburgh, Oliver and Boyd. 641p.

Gómez-Marquez, J. L.; Peña-Mendoza, B. I.; Salgado-Ugarte, H. \& Guzmán-Arroyo, M. 2003. Reproductive aspects of Oreochromis niloticus (Perciformes: Cichlidae) at Coatetelco lake, Morelos, Mexico. Revista de Biología Tropical 51:221-228.

Gomiero, L. M. \& Braga, F. M. S. 2003. Relação peso-comprimento e fator de condição para Cichla cf. ocellaris e Cichla monoculus (Perciformes, Cichlidae) no reservatório de Volta Grande, rio Grande - MG/SP. Acta Scientiarum - Biological Sciences 25:7986.

2004. Reproduction of species of the genus Cichla in a reservoir in southeastern Brazil. Brazilian Journal of Biology 64(3B):613-624.

Goodwin, N. B.; Balshine-Earn, S. \& Reynolds, J. D. 1998 Evolutionary transitions in parental care in cichlid fish. Proceedings of the Royal Society B 265:2265-2272.

Gurgel, H.; Barbieri, G. \& Vieira, L. 1994a. Biologia populacional do "cará", Cichlasoma bimaculatum (Linnaeus, 1754) (Perciformes, Cichlidae) da lagoa Redonda, Nízia Floresta/RN. Revista UNIMAR 16:263-273.

1994b. Biologia populacional do jacundá, Crenicichla lepidota (Heckel, 1840) (Perciformes, Cichlidae) da lagoa Redonda, Nízia Floresta/RN. Revista Ceres 41:658-668.

Hartz, S. M.; Peret, A. C. \& Barbieri, G. 1999. Reproduction of Gymnogeophagus lacustris (Reis \& Malabarba, 1988), an endemic Neotropical cichlid of Southern Brazil. Ichthyological Exploration of Freshwaters 10:247-253.

Kullander, S. O. 1998. A phylogeny and classification of the South American Cichlidae (Teleostei: Perciformes). In: Malabarba, L. R.; Reis, R. E.; Vari, R. P.; Lucena, Z. M. \& Lucena, C. A. S. eds. Phylogeny and Classification of Neotropical Fishes. Porto Alegre, EDIPUCRS. p.461-498.

Kullander, S. O. 2003. Family Cichlidae (Cichlids). In: Reis, R. E.; Kullander, S. O. \& Ferraris JR., C. J. eds. Check list of the freshwater fishes of South and Central America. Porto Alegre, EDIPUCRS. p.605-654.
Lagler, K.; Bardach, J.; Miller, R. \& Passino, D. 1977. Ichthyology New York, Wiley. 505p.

Lobón-Cerviá, J.; Utrilla, C.; Queirol, E. \& Puig, M. 1993. Population ecology of pike-cichlid, Crenicichla lepidota, in two streams of Brazilian Pampa subject to a severe drought. Journal of Fish Biology 43:537-557.

Mazzoni, R. \& Iglesias-Rios, R. 2002. Environmentally related life history variations in Geophagus brasiliensis. Journal of Fish Biology 61:1606-1618.

MCKAYE, K. R. 1984. Behavioral aspects of cichlid reproductive strategies: patterns of territoriality and brood defense in Central American substratum spawners and African mouth brooders. In: PotTs, G. W. \& Wotton, R. J. eds. Fish reproduction: strategies and tactics. London, Academic Press. p.245-273.

Murray, A. M. 2001. The fossil record and biogeography of the Cichlidae (Actinopterygii: Labroidei). Biological Journal of the Linnean Society 74:517-532.

NoAKes, D. L. G. \& Balon, E. K. 1982. Life histories of tilapias: an evolutionary perspective in the biology and culture of tilapias. In Pullin, R. J. V. \& Lowe-McConnell, R. H. eds. The biology and culture of tilapias. Manila, ICLARM. p.61-82.

PAYne, A. I. 1986. The Ecology of Tropical Lakes and Rivers. New York, John Wiley. 301p.

Peters, H. M. \& Berns, S. 1982. Die maulbrutpflege der cichliden. Untersuchangen zur evolution eines verhaltensmusters. Zeitschrift für Zoologische Systematik und Evolutionsforschung 20:18-52.

Pianka, E. R. 1970. On r- and K-selection. The American Naturalist 104:592-597.

Reis, R. E. \& Malabarba, L. R. 1988. Revision of the Neotropical cichlid genus Gymnogeophagus Ribeiro, 1918, with descriptions of two new species (Pisces: Perciformes). Revista Brasileira de Zoologia 4:259-305

SANTOS, E. P. 1978. Dinâmica de populações aplicada à pesca e piscicultura. São Paulo, HUCITEC/ Editora da Universidade de São Paulo. 129 p.

SAntos, G. O. \& Fontoura, N. F. 2000. Dinâmica reprodutiva de Geophagus brasiliensis (Quoy \& Gaymard, 1824) no açude Águas Belas, Viamão, Rio Grande do Sul (Teleostei - Cichlidae). Pesquisa Agropecuária Gaúcha 6(1):131-144

SATo, Y. \& Godinho, H. P. 1988. A questão do tamanho de primeira maturação dos peixes de Três Marias, MG. In: Encontro Anual de Aqüicultura de Minas Gerais. Coletânea de resumos dos Encontros da Associação Mineira de Aqüicultura (AMA): 1982-1987. Brasília, CODEVASF. p.93-94.

Souza, J. E.; Fragoso-Moura, E.; Fenerich-Verani, N.; Rocha, O. \& VERANI, J. R. 2008. Population structure and reproductive biology of Cichla kelberi (Perciformes, Cichlidae) in Lobo Reservoir, Brazil. Neotropical Ichthyology 6:201-210.

VAzzoler, A. E. A. M. 1996. Biologia da reprodução de peixes teleósteos: teoria e prática. Maringá, EDUEM. 169p.

Vazzoler, A. E. A. M. \& Menezes, N. A. 1992. Síntese de conhecimentos sobre o comportamento reprodutivo dos Characiformes da América do Sul (Teleostei, Ostariophysi). Revista Brasileira de Biologia 52:627-640.

WinemilleR, K. O. 1989. Patterns of variation in life history among South American fishes in seasonal environments. Oecologia 81:225-241. 